\title{
701 断面積が変化する管内気柱振動モードの実験解析
}

\section{Experimental Analysis of Oscillation Modes in an Air-Filled Tube with Cross-Sectional Area Change}

\author{
○学 瀬尾 則善（埼玉大院） 正 川橋 正昭（埼玉大·工） 正 平原 裕行（埼玉大·工） \\ Noriyoshi, SEO, Graduate School of Science and Engineering, Saitama University \\ Masaaki KAWAHASHI, Faculty of Engineering, Saitama University \\ Hiroyuki HIRAHARA, Faculty of Engineering, Saitama University
}

\begin{abstract}
When an air-column in a closed tube with constant cross-section is driven at resonance frequency by a piston oscillating at one end, a large amplitude acoustic standing wave is induced in the tube with propagating shock waves. In such cases, the increase of oscillation amplitude is limited by acoustic saturation caused by shock wave formation. In the recent engineering application of acoustic resonance in a tube, it is the main factor to realize large amplitude oscillations. In order to avoid the acoustic saturation, a tube with cross-sectional area change along the tube axis is used. In this report, the acoustic standing wave induced in a tube, which has cross-sectional area contraction from the driving end toward the closed end, has been investigated experimentally at the viewpoint of shockless resonance.
\end{abstract}

Key Words : Acoustic Standing Wave, Finite Amplitude Wave, Shockless Resonance

\section{1. 緒言}

管内音響定在波現象は古典的な問題であるが、最近、その工 学的応用が注目されている。それらは、熱音響効果による冷却 効果の泠凍機への応用や、管閉端で生じる大振幅圧力変動の圧 縮機動作への応用などである。このような工学的応用において は、管内に大振幅定在波を発生、維持させることが求められる。 管内の大振幅定在波は、ピストン駆動によるほぼ両端閉止条件 での気柱共振か、スピーカーを用いた一端開放による気柱共振 により発生させることができる。前者において、断面一定の管 を用いると、極めて微小なピストン振動振幅の状態から衝撃波 形成による音響飽和が生じ、管内圧力変動振幅の増加が制限さ れる。この衝摮波発生現象については、Chester ${ }^{(1)}$ の理論解があ る。熱音響効果の基礎的特性を調べる実験的解析では、一端開 放管が多く用いられており、比較的大きな圧力変動振幅まで、 衝撃波発生は観測されていない。その理由については、開口端 における逆位相反射や反射遅れなどの境界条件の違いによって 基本的に説明される。

ピストン駆動の場合でも、駆動端から閉止端に向かって断面 積が縮小する管を用いると音響飽和が緩和され、衝撃波発生を 遅らせて大振幅共振状態を実現することが可能となる。このこ とは、音響圧縮機の実現を目指したいくつかの報告(2)の中で示さ れており、その理論的、数值的解析についての報告(3)(4)もある。

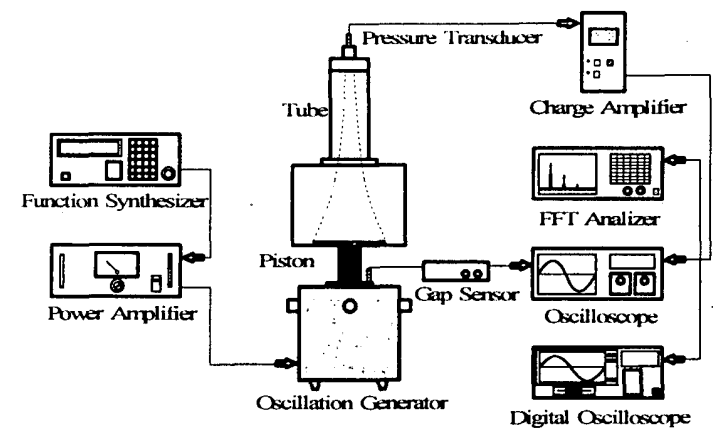

しかし、断面縮小管内の大振幅波動現象についての詳細な解 析は、理論的にも実験的に十分でない。本報告では、断面縮小 管内波動現象の解析の基礎となる、管内気柱振動モードについ て実験的に調べた結果を示す。

\section{2. 実験装置}

本報告で用いた実験装置の概略が、図 1 に示されている。管 断面の縮小については、様々な関数形が考えられ、それぞれの 応用に対応して最適形状を決定しなければならないが、本報告 では、線形音響理論において、その波動特性の詳細が明らかに されている指数関数状断面積縮小管を基準モデルとして用いる。 管長さは、 $300 \mathrm{~mm}$ 、駆動面直径は $100 \mathrm{~mm}$ 、閉止端直径は $10 \mathrm{~mm}$ であり、断面縮小率は、100である。なお、比較のために、同 一駆動面半径、管長さを有する直管についても、波動特性の確 認を行っている。ピストンの駆動源は電磁駆動型加振器であり、 駆動周波数は精度 $0.01 \mathrm{~Hz}$ のシンセサイザーにより調整される。 駆動ピストン振動振幅測定には、感度 $0.1 \mu \mathrm{m}$ の渦電流型微小変 位計が、管内開端圧力変動測定には、電荷型圧力変換器が用い られる。なお、ピストン振動振幅值は、本実験で使用した管の 基本振動周波数の関係から、最大 $15 \mu \mathrm{m}$ 程度に制限される。 上記実験装置によりもたらされる管内大振幅定在波により、 その非線形効果として、音響流が生じる。音響流構造は、気柱 振動モードに関連することから、その可視化観察を行い、管内 波動状態を考察する。音響流の可視化には、アルゴンイオンレ 一ザ出カビームをシリンドリカルレンズにより広げたシート光 を用い、管中心軸を含む断面を可視化する。画像記録には、デ ジタル CCD カメラが用いられる。なお、光散乱粒子には、プロ ピレングリコールを主成分とする配合油を用いた加熱式スモー ク発生器からのスモーク粒子を用いた。

3. 実験結果

はじめに、使用した管内気柱振動の周波数特性を図 2 に示す。

Fig.1 Schematic of experimental setup 


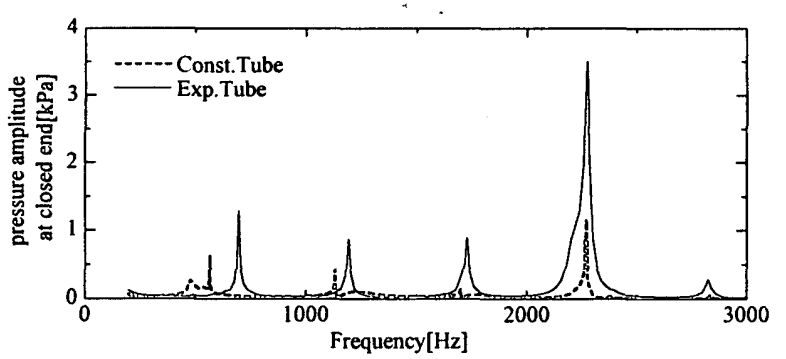

Fig.2 Frequency spectram

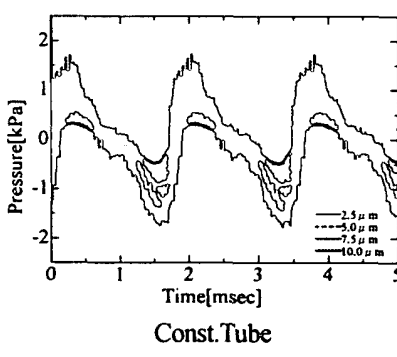

(Ist mode, $\mathrm{f}=566.5 \sim 567.0 \mathrm{~Hz}$ )

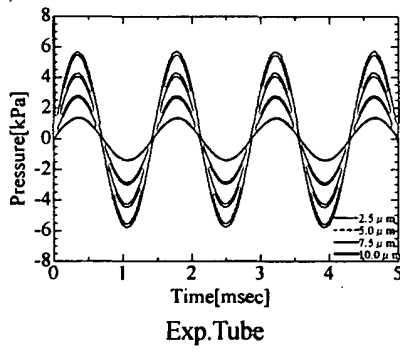

(1st mode, $f=696.6 \sim 696.8 \mathrm{~Hz}$ )
Fig.3 Pressure histories at closed end for variouss amplitude of piston (constant tube and exponential tube)

使用した加振器の周波数特性の関倸から、ピストン振動変位 を一定にすることは困難であるため、加振器入力一定の条件で 得られたものである。この結果は、直管内気柱振動は、基本振 動周波数に対して、整数倍の高次振動モードが現れているが、 指数関数状断面縮小管では、高次振動周波数は基本成分の整数 倍とはならない。Ilinskii ら(3)は、このような周波数特性が音響 飽和を抑制していると説明している。圧力変動振幅値は、何れ のモードにおいても、指数関数管において大きな值を示してい る。なお、 $2.3 \mathrm{kHz}$ 付近での振幅の増加は、加振器共振点の近傍 の影響で、ピストン振幅が増加しているためと思われる。

つぎに、基本振動状態での、ピストン振動振幅による管閉端 圧力変動波形の変化を図 3 に示寸。この結果、直管では微小ピ ストン振幅から波形歪が現れ、振幅の増加と共に衝繁波発生が 見られる。指数関数管では、波形歪は観測されず、同一ピスト ン振幅に対して、ショックレス共振が実現していることがわか る。

本実験でピストン振動振幅は極めて小さく、管内気柱振動に 対する境界条件は、ほぼ両端閉止であるため、管内には、管長 を $1 / 2$ 波長とする周波数の整数倍に相当する振動モードが生じ る。管内気柱振動の振幅増加に伴って、この振動モードに応じ た音響流が生じる。すなわち、音響流は定在波速度変動の腹お よび節部を境にして、ストークス層内での流れの方向が変化す るため、定在波モードに対応した構造を有する。とくに熱音響 効果応用においては、この管内定在波における節および腹の位 置を特定する必要がある。そこで、振動モードに対して、どの ような音響流構造が生じているかを可視化により、明らかにす る。はじめに基本振動状態の音響流可視化結果が、図 4 に示さ れている。この結果、指数関数管内においても節部相当位置が 明確に生じる定在波が形成され、その位置が管の $1 / 2$ 長さ位置 より大きく駆動面側にずれていること、音響流構造境界面が管
軸に垂直な平面状ではなく湾曲していることなどがわかる。後 者は、基本振動状態での管内伝ぱ波面が平面波状でないことを 示している。図 5 には、高次の気柱振動による音響流構造の可 視化結果が示されており、各次数に応じた構造が確認される。

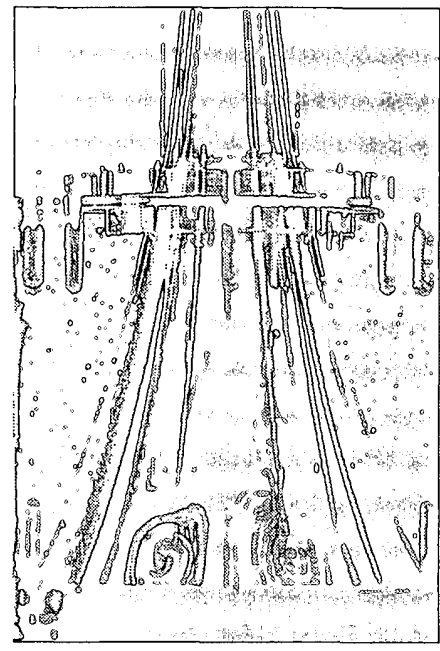

Fig.\& Visualization of acoustic streaming in an exponential turbe (1st mode, $\mathrm{f}=690.5 \mathrm{~Hz}$ piston amplitude: $10.0 \mu \mathrm{m})$

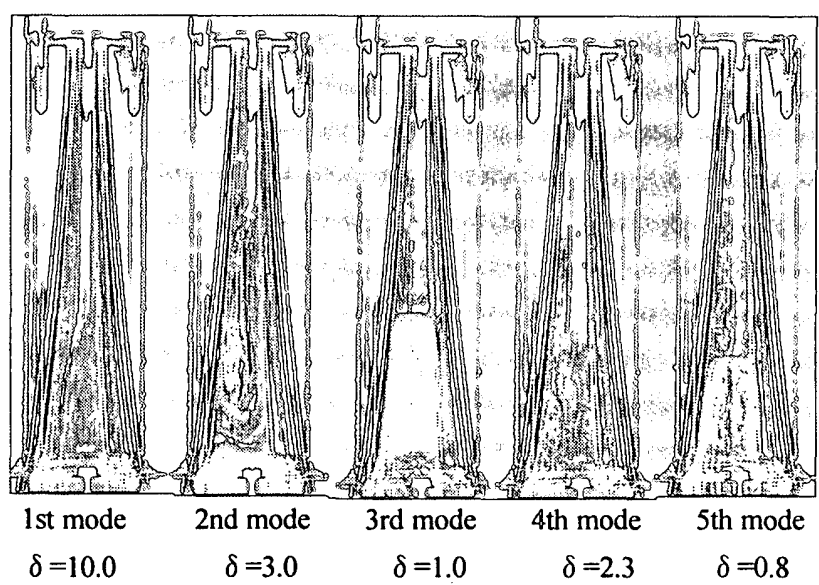

Fig. 5 Visualization of acousstic streaming for various oscillatory modes in am exponential trube ( $\delta$ :piston amplitude[ $\mu \mathrm{m}]$ )

\section{4. 結言}

指数関数状断面縮小管内の定在波についての実験解析により、 大振幅のショックレス定在波を実現することが可能であること が示された。音響流の可視化により、管内で生じる各次数の振 動モードが確認された。音響圧縮機、熱音響泠涷機などへの応 用を考える上では、さらに異なった形状の管内定在波について 明らかにしていく必要がある。

\section{参考文献}

(1) Chester, W., Resonant oscillation in closed tubes, J. Fluid Mech., 18, part 1, (1964),44-64.

(2) Lawrenson, C. et al., Measurements of macrosonic standing waves in oscillating closed cavities, J.A.S.A., 104(1998), 623-636.

(3) Y.A. Ilinskii, et al., Nonlinear standing waves in an acoustic resonator, J.A.S.A., 104,(1998),2664-2674.

(4) Kawahashi,M. et al., Large Amplitude Oscillation of Air Column in a Closed Ductwith Varying Cross-Sectional Area, Proc. 4 th KSME/JSME FEC-98, (1998), 405-408. 